Revista Iberoamericana, Vol. LXXVI, Núm. 232-233, Julio-Diciembre 2010, 583-600

\title{
UNA PROPUESTA TESTIMONIAL ALTERNATIVA: SEÑORES BAJO LOS ÁRBOLES, DE MARIO ROBERTO MORALES
}

\author{
POR \\ Henry Thurston-GriswOLd \\ Juniata College
}

Antes de que se hiciera pública la controversia en torno a la veracidad factual del célebre testimonio de Rigoberta Menchú, ${ }^{1}$ el escritor y revolucionario guatemalteco Mario Roberto Morales ya había concebido y compuesto un modelo alternativo que responde a las limitaciones de los testimonios canonizados que pretenden representar las experiencias de un grupo social completo mediante la narración de una sola voz testimoniante. En la introducción al testimonio de Menchú, por ejemplo, ésta declara hablar por y contar la historia de todos los guatemaltecos pobres (21), afirmación que inspiró el título del libro del antropólogo David Stoll que pone en tela de juicio la verdad de algunos de los hechos narrados por la Premio Nobel de la Paz.

La verdad histórica de este tipo de narración testimonial siempre puede cuestionarse por el compromiso sociopolítico del narrador, el cual genera acusaciones de parcialidad, y por la intención retórica implícita o explícita de incitar a los lectores a apoyar la causa de la voz testimoniante. Pero más allá de cargos de subjetividad y fines propagandísticos, el modelo testimonial consagrado corre el riesgo de crear una relación demasiado simplista y unidimensional de una realidad social compleja y en muchos aspectos

1 El antropólogo estadounidense David Stoll ha sido la figura central en el cuestionamiento de la veracidad y la autoridad del testimonio de Menchú. Según el testimonio de John Beverley en el prefacio de su libro Testimonio: On the Politics of Truth (University of Minnesota Press, 2004), Stoll expresó por primera vez en un foro público sus dudas respecto de la veracidad de algunos de los detalles del testimonio de Menchú, en un congreso académico organizado en 1990 en torno al tema "'Political Correctness' and Cultural Studies" en la universidad de California, Berkeley (xiv). Sin embargo, la controversia no alcanzó una difusión y una resonancia más generales hasta la publicación de un artículo en el New York Times por Larry Rohter el 15 de diciembre de 1998 ("Tarnished Laureate: Nobel Winner Accused of Stretching the Truth in her Autobiography"), un reportaje especial publicado en la portada que reseñaba las acusaciones y conclusiones del flamante libro de Stoll, Rigoberta Menchú and the Story of all Poor Guatemalans. Para más perspectivas y análisis sobre la controversia, las antologías de textos reunidos por Arturo Arias, The Rigoberta Menchú Controversy (2001), y por el mismo Mario Roberto Morales, Stoll-Menchú: la invención de la memoria (2001), son obras de consulta imprescindibles. 
contradictoria. La denuncia de la injusticia social desde una sola perspectiva, aunque afirme ser representativa de toda una clase o grupo social, no puede dar cuenta de la multiplicidad de ideologías, intereses, creencias, actitudes y valores que condiciona la conducta de los individuos, los grupos y las instituciones.

El modelo testimonial canonizado también se limita al hacer caso omiso del papel de la ficción en la representación de sus verdades. En la misma época de los años setenta y ochenta en que historiadores como Hayden White reconocían la imposibilidad de eliminar elementos de ficción de los textos históricos por su carácter narrativo, ${ }^{2}$ los "autores" de testimonios rehusaban reconocer los elementos ficticios de sus reconstrucciones narrativas de hechos históricos, temiendo sin duda disminuir la fuerza de su denuncia testimonial. La autoridad del testimonio se deriva del hecho de ser testigo ocular de ciertos eventos y de establecer un pacto implícito con los lectores de relatar "la verdad y sólo la verdad” de los sucesos presenciados. Cualquier insinuación de ficcionalidad socavaría las bases de este pacto, ya que la ficción se asocia con la invención y la mentira.

En el prólogo a la segunda edición de Señores bajo los árboles, titulado "Oralitura y testinovela” y fechado octubre del 2004, Mario Roberto Morales explica la génesis de la obra que él mismo califica de propuesta híbrida (17) y que bautiza testinovela (9). El vocablo inventado señala la fusión entre el testimonio y la novela, pero como declara Morales, lo novelesco se pone al servicio de la verdad testimoniada (13). Las voces, recogidas de testimonios de sobrevivientes guatemaltecos que él había obtenido de varias fuentes en Costa Rica y Nicaragua durante su estancia en estos países durante los años ochenta, le inspiraron a "concebir un libro utilizando como materia prima muchas voces indígenas para, a partir de ellas, crear una estética del horror convirtiendo sus hablas en una lengua literaria que diera cuenta de aquella traumática experiencia colectiva” (8). Morales destaca el papel subordinado pero esencial de la ficción, puesto que el factor estructurador de la narración son las voces testimoniantes, mientras la ficción realiza el "reordenamiento de los elementos que componen un hecho que ocurrió (o no) en la realidad, para darle viabilidad narrativa y sentido deliberado" (16). Por consiguiente, la ficción elabora un lenguaje literario para el testimonio y cumple "una función artesanal meramente viabilizadora de aquellas voces y aquellas hablas, marcadas a fuego por el terror" (9).

Según esta concepción de la testinovela, el escritor profesional procesa y ordena las voces testimoniantes "para ofrecer una visión totalizadora del hecho que le interesa a su vez testimoniar. El escritor testimonia mediante testimonios con la finalidad de preservar la memoria colectiva y reciclar la identidad” (9). Morales sitúa su obra dentro de la larga

2 Véase, por ejemplo, su libro The Content of the Form: Narrative Discourse and Historical Representation, para un estudio sugestivo del impacto que tiene la forma narrativa en la representación de la verdad histórica.

Revista Iberoamericana, Vol. LXXVI, Núms. 232-233 Julio-Diciembre 2010, 583-600
ISSN 2154-4794 (Electrónico) 
tradición testimonial que se remonta a las crónicas de la conquista española y los libros mágicos y rituales de los indígenas como el Popol Vuh (10), pero también destaca que para lograr la "estética testimonial del horror" que se propone, su libro "tendría que ser, pues, polifónico, plural, diverso, según la experiencia individual de las víctimas” (8). Reconoce asimismo al final del prólogo el carácter tendencioso y contestatario del texto, o sea su función comprometida, declarando que: "Mediante él, ajusto cuentas con las élites de poder de mi país, a las cuales se vino a sumar la izquierda representada por la dirigencia de la URNG [Unidad Revolucionaria Nacional Guatemalteca] que, junto con el ejército, hizo de los acuerdos de paz el mecanismo para encubrirse mutuamente los crímenes de guerra que cometieron y que aparecen ilustrados en mi libro” (18). ${ }^{3}$

En este ensayo, pienso examinar la propuesta testimonial concretada en Señores bajo los árboles a partir de las reflexiones teóricas y críticas del mismo autor y mi propio análisis de los principales elementos estéticos y éticos del texto. Espero demostrar que el modelo concebido y ejecutado por Mario Roberto Morales constituye un camino viable y fructífero para dar a conocer la injusticia social y las atrocidades perpetradas durante el conflicto armado interno de Guatemala. En el contexto de la literatura hispanoamericana, desde Borges se suele aceptar que no hay una línea divisoria fija entre la ficción y la realidad, y que nuestras verdades son construcciones provisionales condicionadas no sólo por la razón, la observación y el cientificismo empírico, sino también por la imaginación y por nuestros deseos y temores más profundos. Una vez rechazada la oposición binaria mutuamente exclusiva entre la verdad y la ficción, es más factible reconocer la validez de utilizar recursos retóricos propios de la ficción a fin de representar, denunciar y difundir a un público lector más amplio el genocidio sufrido por la población civil indígena durante la sangrienta guerra civil guatemalteca.

Como ya se ha afirmado, un rasgo fundamental de la modalidad testimonial es el establecimiento de un pacto entre el (los) emisor(es) y los receptores de la narración, según el cual la voz testimoniante asegura contar hechos reales que ella o él mismo

\footnotetext{
3 En las entrevistas que Edward Waters Hood y Eduardo Guízar Álvarez realizaron con el autor, Morales destaca el diálogo intertextual entre Señores bajo los árboles y el testimonio de Menchú, la obra "indigenista” de Miguel Ángel Asturias y la denuncia testimonial de fray Bartolomé de las Casas. En el caso del testimonio de Menchú, declara su intención de explotar unas posibilidades estético-literarias y unas formas de contrainsurgencia no tratadas en el libro de Burgos y Menchú (Hood 541-42). En el segundo caso, Morales reconoce a Asturias como un referente ineludible al tratar el tema del indígena guatemalteco, pero opta por representar elementos de la cosmogonía maya desde el punto de vista de los brujos y los chamanes en este contexto de la represión contrainsurgente, algo que Asturias no había tratado en sus obras (Guízar 89-90). Y por último, el autor afirma haberse inspirado en "el muestreo de todos los horrores que hacen los españoles” (Guízar 90) de fray Bartolomé para narrar y denunciar el horror y el terror sufridos por la población indígena en este último capítulo de una larga historia de explotación y opresión.
}

Revista Iberoamericana, Vol. LXXVI, Núms. 232-233 Julio-Diciembre 2010, 583-600
ISSN 2154-4794 (Electrónico) 
vivió y en muchos casos sufrió en carne propia. En Señores bajo los árboles, Morales inicia la obra con una aseveración explícita de la veracidad de lo narrado: "En este libro todas las voces son reales. El requisito de la ficción radica en la conversión artesanal de esas voces en una estructura y un lenguaje que no son ni fueron ni tienen por qué haber sido reales [...]. Este es un caso en el que la realidad abruma a la ficción, de modo que ésta debe servirla con la humildad del caso” (19). De esta manera, reivindica la autoridad narrativa que los lectores suelen conceder a los textos históricos y a los de otras disciplinas de las ciencias sociales como la antropología que pretenden indagar y expresar la verdad histórica.

Además de este breve prefacio de reivindicación testimonial, el autor incluye dos otras secciones introductorias. La primera, una recopilación de citas de cinco textos y autores canónicos -el Popol Vuh, el Rabinal Achí, El libro de los libros de Chilam Balam, Bartolomé de las Casas y Don Juan Matus- sirve para evocar la representación de la muerte y la violencia en la cosmovisión maya, y para relacionar la represión actual con las “carnicerías tan inhumanas” (21) de la conquista española. ${ }^{4}$ La última cita, que se atribuye al brujo yaqui mentor del controvertido antropólogo y escritor Carlos Castaneda, de carácter más bien filosófico, afirma la igualdad postrera de los opresores y los oprimidos impuesta por la muerte y constata asimismo la supervivencia de la cosmovisión indígena. La segunda sección introductoria dedica la obra a todas las voces testimoniantes representadas en el libro, pero a la vez insiste en ubicar la escritura de este texto temporalmente en relación a dos momentos: el quinto centenario de la conquista, o sea el inicio de la represión de los pueblos indígenas por los conquistadores europeos; y el décimo aniversario “del inicio de lo peor” (23), referencia a la época más brutal del conflicto armado, la campaña contrainsurgente de tierra arrasada emprendida por el ejército guatemalteco, la que resultó en la destrucción completa de centenares de pueblos indígenas.

La decisión de incorporar múltiples voces testimoniantes en el libro-casi dos docenas en total- motiva el empleo de una estructura narrativa fragmentaria, y por lo tanto, la obra se divide formalmente en tres secciones que se titulan "Primeros fragmentos de la explosión” (10 fragmentos), “Otros fragmentos”(8 fragmentos) y “Aún otros fragmentos” (3 fragmentos). La imagen de la explosión evoca la ruptura de algo previamente entero, y tal fragmentación de la narración plantea el reto estético de cómo ordenar todas estas voces para darles cierta coherencia y unidad. A diferencia de la narrativa posmoderna que se sirve de la fragmentación formal para señalar el fracaso de los paradigmas

4 En realidad, Morales establece este vínculo desde el principio mediante el juego de palabras del subtítulo de la obra, modificado levemente de la conocidísima obra testimonial de fray Bartolomé de las Casas, el cual es a mi juicio más exacto en la versión de Morales: "Brevísima Relación de la Destrucción de los Indios”.

Revista Iberoamericana, Vol. LXXVI, Núms. 232-233 Julio-Diciembre 2010, 583-600
ISSN 2154-4794 (Electrónico) 
totalizadores de la modernidad y la pérdida de las llamadas “narrativas maestras”, los textos testimoniales buscan comunicar un mensaje claro y convincente que posea la fuerza retórica de rebatir la historia oficial de los que detentan el poder. En este sentido, el imperativo ético testimonial de romper el silencio y denunciar la injusticia entra en conflicto con la propuesta de Morales de incluir una variedad de voces, perspectivas y vivencias en su testinovela, y el autor se ve obligado a recurrir a varios recursos de la ficción para lograr la visión totalizadora y comprehensiva que se propone.

Uno de los recursos clave del que se vale Morales es la creación de un marco narrativo enraizado en las culturas mayas que abarca desde el nacimiento hasta la muerte. Cada una de las tres secciones comienza y termina con un fragmento corto escrito en letra cursiva que resalta un aspecto importante de lo que se denomina la Costumbre. En la mayoría de los fragmentos, el narrador no se identifica explícitamente, pero en el cuarto y el quinto se identifica como brujo, o sea guía espiritual de la comunidad. Por la unidad temática de estos fragmentos, la colocación al principio y al final de cada sección, el estilo discursivo consistente y el uso de la letra cursiva, sería razonable concluir que el brujo es el comentarista que proporciona este marco cultural y también presta testimonio acerca del impacto destructivo de la represión sobre la cultura maya. ${ }^{5}$ El primer fragmento narra las prácticas y las ceremonias relacionadas con el nacimiento. ${ }^{6}$ El segundo, al final de la primera sección, explica el valor simbólico de los dibujos bordados en los huipiles de las mujeres. El tercero, que da inicio a la segunda sección, relata las costumbres relacionadas con el matrimonio, y el cuarto comenta el proceso de iniciación por el que se pasa para hacerse brujo. El quinto fragmento subraya la gran prueba que la represión significa para el pueblo maya, más dura que la guerra de Conquista según el brujo. Y el último fragmento gira en torno al tema de la muerte, pero en lugar de describir los rituales mayas asociados con la muerte, el narrador denuncia los intentos de aniquilar la cultura maya: "Matan no sólo a la gente sino nuestra Costumbre, nuestra cultura están matando para que los niños que van naciendo no tengan memoria de sí mismos [...]” (166).

5 En la entrevista con Hood, Morales indicó que la forma literaria de los fragmentos culturales es una invención suya, pero que los contenidos representan una "síntesis de voces" derivada de lecturas y conversaciones con informantes indígenas (539).

6 Se intercala un fragmento adicional redactado en letra cursiva inmediatamente después de este primer fragmento para presentar al personaje colectivo del ejército y denunciar anafóricamente las masacres (Morales, Stoll-Menchú: la invención de la memoria) que éste lleva a cabo: "ellos los que queman los ranchos [...] ellos son los que acorralan a los hombres para matarlos...ellos despanzurran a los niños [...] ellos son los que rasgan las barrigas de las mujeres, les sacan a los chiquitos que todavía no han nacido y los echan a los perros después de partirlos en dos desgajándolos por las piernas como cangrejos [...]" (28) Es preciso notar que este fragmento de tres cuartos de página se reproduce sin letra cursiva al principio del penúltimo fragmento del libro, el testimonio de un miembro de las Comunidades de Población en Resistencia, creando así otro marco narrativo de denuncia de la violencia.

ISSN 0034-9631 (Impreso) 
Otro recurso literario empleado por Morales para entretejer los fragmentos de la narración es "la historia de un personaje inventado a partir precisamente de la visión del mundo que vertían las voces testimoniantes" (Señores, "Prólogo" 11). Este personaje, el cohetero Toribio de León, se presenta en el primer fragmento que sigue a los dos breves redactados en letra cursiva. El autor se sirve de la narración omnisciente para contar el reclutamiento forzado del joven Toribio por el ejército, que irrumpe en el pueblo durante una fiesta patronal para llevarse a todos los jóvenes mayores de dieciocho años. Además de verse obligado a prestar servicio militar, Toribio tiene que presenciar la ejecución bárbara de su padre, uno de tres miembros inocentes del pueblo (cohetero, cura y sacristán) acusados de subversión por el ejército, rociados de gasolina y quemados vivos. Toribio, convertido en kaibil, la fuerza de élite del ejército especializada en la lucha contrainsurgente, vuelve a aparecer en cinco otros fragmentos, y brinda la perspectiva del soldado indígena obligado a participar en las masacres de sus hermanos indígenas. ${ }^{7}$

En el primero de estos fragmentos, él se presenta como instrumento del terror, degollando a un hombre con su machete, asesinando a una mujer y aplastando a su hijo contra un peñasco rocoso, como parte de una operación diseñada para aterrorizar y subyugar a la población. El segundo fragmento narra la masacre del pueblo de Rabinal, localizado en el departamento de Baja Verapaz y una de las zonas más golpeadas por el conflicto armado. Se yuxtapone la narración de los hechos desde el punto de focalización de Toribio con un testimonio en letra cursiva desde la perspectiva de los habitantes indígenas. El narrador omnisciente vuelve a contar desapasionadamente las atrocidades cometidas por los soldados, pero también subraya que éstos son subordinados que sólo cumplen las órdenes de sus superiores, y explora los sentimientos de impotencia de Toribio. Tras unas reflexiones sobre la moral del bien y del mal juntos, la moral de Kukulkán, la Serpiente Emplumada, ilustrada en El Rabinal Achí y en la adoración en Guatemala de San Simón o Maximón, el narrador agrega la conclusión que saca Toribio: "Nada puede hacer solito, piensa, por eso decide seguir cumpliendo con lo que le ordenen mientras dure el servicio militar. Quiere, eso sí, estar consciente de lo que ocurre. Si tiene que hacer el mal que no desea hacer pero está consciente de que no puede remediarlo, piensa, la moral de Kukulkán está con él [...]” (83).

El papel de Toribio en el tercer fragmento, que narra el robo "legal" de tierras indígenas realizado por un licenciado en San Antonio Aguascalientes, un pueblo indígena

\footnotetext{
En la entrevista con Hood, Morales se refiere a la falta absoluta de testimonios de este tipo de personaje, lo cual le impuso la necesidad de imaginar los trastornos psicológicos e inventar al personaje, sirviéndose sólo del caso del testimonio de un policía militar que le contó un amigo escritor y guiándose por su deseo de crear un personaje realista que representara con fidelidad a los miles de indígenas que se vieron forzados a convertirse en los asesinos de sus hermanos indígenas (540-51). En su entrevista con Guízar, el autor afirma haberse inspirado en parte para la creación de Toribio de León en la figura de Luis de Lión, el escritor maya y compañero de Morales desaparecido por el ejército en 1984, declarando que "[l]o bueno de Toribio es de Luis” (88).
}

Revista Iberoamericana, Vol. LXXVI, Núms. 232-233 Julio-Diciembre 2010, $583-600$
ISSN 0034-9631 (Impreso) 
cerca de Antigua Guatemala, es secundario pero vuelve a destacar el conflicto interior que él experimenta al verse forzado a desempeñar el papel de verdugo: “[...] Toribio el cohetero suda: 'Un indio más’, piensa, 'hasta cuándo voy a seguir matando indios': sabe que como él es kaibil sus compañeros esperarán que sea él quien ate de pies y manos al alcalde con un cordel de nylon, que sea él quien, después de que entre todos lo torturen, lo quemen, le arranquen el pelo, le corten los dedos y la lengua, le saquen los ojos y los dientes [...], que sea él, Toribio, quien lo estrangule con otro cordel de nylon [...]” (133).

El cuarto fragmento combina la lectura y los escritos de Toribio para presentar la estrategia y las tácticas militares y para poner de manifiesto la profunda ambivalencia y confusión que siente Toribio. Se alternan tres trozos del manual instructivo de los soldados -sobre las operaciones de ataque, operaciones de inteligencia y operaciones psicológicas-con las observaciones y reflexiones del personaje sobre sus actos. Después de apuntar en su libreta la participación suya en un operativo en que la tropa obligó a los patrulleros civiles a matar a siete hombres en un cantón del pueblo de Zacualpa, Toribio escribe: “A nosotros nos duele todo esto porque nos cuesta seguir matando a nuestra gente. Lo mismo ocurrió en el / municipio de Joyabaj. Nos llevan a otras regiones, a otras aldeas para matar a nuestra gente” (141-42). Al final de este fragmento, Toribio describe el valor del proceso de escritura para aclarar sus ideas y encontrar su camino. El fragmento se acaba abruptamente en medio de la palabra terminar, dejando al lector in medias res al igual que el personaje. Convendría citar el principio y el final de esta última parte del diario de Toribio como ilustración de cómo el autor utiliza este personaje individualizado pero representativo a fin de mostrar el impacto psicológico de la guerra en los soldados indígenas:

Termino de llenar esta libreta el día de hoy, siempre a escondidas de mis compañeros, antes de quemarla. Es la número cinco. Que mis palabras se las lleve el humo, no importa. En el humo van las cargas de mi pensamiento, de mi palabra que ofrezco a Corazón del Cielo. Sólo así puedo seguir con todo esto hasta que acabe mi servicio militar [...]. Por ratos no sé qué hacer y hasta siento como si no quisiera que todo esto terminara: no sé quién soy a veces, por eso escribo estas cosas para después quemarlas y verlas arder y no olvidarme de mi tata ni de mi pueblo ni de que soy cohetero de profesión y que todo esto de los kaibiles se va a acabar pronto y lo voy a olvidar: voy a conseguirme una mujer en la capital y tal vez nos vayamos a probar suerte a Los Ángeles [...] Se me acaba el papel: quiero y al mismo tiempo tengo miedo de que esta guerra termi/. (142)

La última aparición de Toribio ocurre en el penúltimo fragmento de la obra, el cual se dedica a dar testimonio sobre la experiencia de las CPRs, las Comunidades de Población en Resistencia, quienes ni se refugian en México ni se entregan al ejército, sino que se ocultan en la montaña y en la selva y viven una precaria existencia nómada

\footnotetext{
Revista Iberoamericana, Vol. LXXVI, Núms. 232-233 Julio-Diciembre 2010, $583-600$
ISSN 2154-4794 (Electrónico) 
huyendo de las fuerzas armadas. Su intervención en este fragmento de 18 páginas es mínima y se reduce a la mención de una maestra de escuela de Rabinal que cuenta indirectamente por medio de otra voz testimoniante los detalles de esa masacre, ya narrada en dos fragmentos de la primera sección desde tres otras perspectivas (72-84), y se señala de nuevo la vacilación de Toribio al quedarse atrás durante la matanza. La maestra Tenchita relata que ella y siete niños "se escondían cuando un oficial le gritó: ‘¿Qué pasa Toribio, quemá, dispará, esta no es feria de bombas voladoras!’ [...]” (159). La participación de Toribio en este quinto fragmento no es esencial, pero tampoco es gratuita, puesto que enlaza los diversos testimonios y los trágicos eventos narrados, y proporciona cierta cohesión a la fragmentación ocasionada por la destrucción de centenares de comunidades indígenas.

El lenguaje literario utilizado por el autor, escueto y directo por lo general, también contribuye a la cohesión de los fragmentos. Con la excepción de dos pasajes de una extensión de unas tres páginas, ${ }^{8}$ Morales emplea un estilo discursivo conciso con relativamente pocas figuras retóricas a fin de no distraer de los hechos testimoniados. Por otra parte, para no incurrir en la inverosimilitud, la limitada educación formal de casi todos los testigos exige un lenguaje sencillo, sin tropos atrevidos. La mayoría de las imágenes se toma de la realidad cotidiana y la naturaleza. Al contar gráficamente el primer asesinato cometido por Toribio, por ejemplo, se describe los párpados de la cabeza decapitada de Juan que "se le abrieron y cerraron como alas de mariposa [...] [mientras] su cuerpo daba pasitos hacia atrás como un bebé [...]” (69) Sin embargo, el autor no transcribe el discurso literal de las voces testimoniantes. Todas se expresan en un español que suele ser gramaticalmente correcto y accesible para un público lector muy amplio, y el léxico y los modismos característicos del castellano hablado por los indígenas guatemaltecos se limitan al mínimo necesario para evocar el habla de los indígenas. Como afirma Morales en su entrevista con Edward Waters Hood, su propuesta estética está "basada en la oralidad, en el trabajo de los ritmos, de las cadencias, y sobre todo basada en la manera ‘incorrecta’ en que los indios hablan el castellano” (543). Los

\footnotetext{
8 Morales distingue estos dos pasajes del resto de la obra mediante el uso de letra cursiva con negritas para añadir énfasis. Ambos se intercalan en medio de un testimonio -el primero del indígena que lideró el asalto a la finca del licenciado usurpador de tierras y el segundo del brujo que comenta la iniciación de los brujos- y se caracterizan por un estilo más descriptivo, ampuloso y acumulativo. El primero dedica un poco más de dos páginas a la evocación de la ciudad de Antigua en términos físicos, históricos y culturales, señalando lo bello y lo feo, lo bueno y lo malo de este "centro de la humillación de los indios" (127), "ciudad de uñas enterradas, testimonio de la grandeza y de la miseria de España, de la miseria y de la grandeza de Guatemala [...]" (128). El segundo, menos extenso y exuberante, retrata a los brujos de la antigüedad, "los de la ubicuidad absoluta, los viajeros del espacio, los dobladores del tiempo" (143), y relata lo que denomina su "error" de hacerse amigos de los dioses de Xibalbá, el cual produjo el abandono de las grandes ciudades mayas y "el descenso de todas las estirpes a su propio Xibalbá [....]" (144).

Revista Iberoamericana, Vol. LXXVI, Núms. 232-233 Julio-Diciembre 2010, 583-600
ISSN 2154-4794 (Electrónico)
} 
ritmos y las cadencias se establecen principalmente mediante el uso de la puntuación-la elipsis y los dos puntos que subrayan lo fragmentario de los testimonios y señalan las pausas- y por el empleo extenso de la repetición en los fragmentos.

La repetición tanto de imágenes y frases como de ideas, creencias y hechos produce una especie de efecto de espiral que unifica los fragmentos testimoniales. La imagen central de la obra es que el ejército es Xibalbá, es decir, las fuerzas del mal. Se hace esta identificación en los tres primeros fragmentos que se narran en primera persona (49, $57,68)$ y en los dos últimos fragmentos $(159,163,164,166)$ se vuelve a resaltar este papel demoníaco del ejército. Como concluye la primera voz, una activista que se hace guerrillera, al final de su testimonio: “[...] lo único que saco en claro es que Xibalbá son ellos, los del ejército, eso es lo único que saco en claro, porque no quieren que haya más raza india, no quieren que existan ya los mayas: quichés, kackchiqueles, kekchíes, mames [... ] Nos quieren destruir” (49). La catequista del tercer fragmento también utiliza esta imagen al final de su testimonio: "El ejército es Xibalbá, no es Corazón del Cielo, que es Xibalbá, según se mire la cosa, como dicen los brujos [...]. Que si uno busca la oscuridad encuentra a Xibalbá en su propio corazón, por eso los soldados son Xibalbá, porque los entrenan para engrandecer las tinieblas. Lo más doloroso es que todos son indios como nosotros, y su oscuridad se hace más negra” (68). Las dos últimas voces del libro, un miembro de las Comunidades de Población en Resistencia (CPR) y un brujo, reiteran la identificación de "Xibalbá de los Ejércitos" (166), pero el miembro de la CPR también expresa la creencia de que:

...Xibalbá nos cae al pelo aunque nos cause tanto dolor: porque de lo oscuro saldrá la luz cuando la escala musical se haya mordido la cola como el Pájaro Serpiente: del dolor surgirá la dicha como ocurre después de un parto: y de esta larga noche negra saldrá la claridad del día para todas las estirpes, y por fin Corazón del Cielo abrirá su pecho para que la Serpiente Emplumada vuele libre en nosotros y dejemos de / ser indios para ser reconocidos como seres humanos que tienen derecho de luchar, y seremos libres en Kukulkán [...] (164-65)

Otras imágenes y frases repetidas que se relacionan con el ejército -los soldados como "puntitos negros" $(28,148,154,165)$ que llegan a los pueblos indígenas "por oleadas" (28, 148, 149, 151, 165) para matar, y la mantra de los kaibiles, quienes afirman comer "carne humana" y "guerrilleros subversivos" $(76,79,80,116)$ refuerzan este papel destructor del ejército. De igual manera, la narración repetida de las masacres y otras atrocidades cometidas por el ejército en la gran mayoría de los fragmentos confirma la aseveración reiterada de las voces testimoniantes de que el ejército quiere matar o terminar con la cultura maya $(48,59,144,154,166)$. En el fragmento que narra la masacre realizada en Rabinal, la repetición anafórica de "la orden:” (ocho veces a lo largo de dos páginas) pone de manifiesto las tácticas del ejército para destruir la cultura

Revista Iberoamericana, Vol. LXXVI, Núms. 232-233 Julio-Diciembre 2010, 583-600
ISSN 2154-4794 (Electrónico) 
del pueblo maya y eliminar su capacidad y voluntad de ayudar a la guerrilla. Bastarán tres ejemplos de estas órdenes para ilustrar la política genocida de terror adoptada por los estrategas militares: "La orden: herir de muerte, dejar vivos a los subversivos cuando ya no puedan sobrevivir, dejarlos que mueran solos y despacio, asegurarse de que haya testigos y dejarlos huir. /[...] la orden: matar a los cofrades, a los chimanes, a los sajorines, a los brujos, a los ancianos, a los niños pequeños; la orden: matar mujeres embarazadas, sacarles a los hijos del vientre y aplastarlos a la vista de todos” (78-79).

Aunque el ejército constituye el blanco principal de las denuncias testimoniales, también se utiliza el recurso de la repetición para definir y condenar la actuación de la guerrilla desde varias perspectivas. En efecto, la primera crítica proviene de las filas de la guerrilla misma, la activista convertida en guerrillera que expresa su decepción ante el asesinato de la hija del principal de una aldea porque su padre y ella les negaban apoyo a los compañeros (44). Condena asimismo el ajusticiamiento de la gente de las aldeas que se niegan a izar la bandera del EGP (Ejército Guerrillero de los Pobres) y el abandono de la población civil ante las campañas contrainsurgentes del ejército (45). La ejecución de los que no izan la bandera del EGP se vuelve a denunciar a través del fragmento testimonial del responsable de otro grupo revolucionario, el Frente Guerrillero de La Estrella (en formación), quien le informa al comandante guerrillero mediante una carta del fusilamiento de 32 militantes por el EGP (117), ${ }^{9}$ y también se constata esta práctica en el testimonio del miembro de las CPR (155). En cuanto a la denuncia del abandono de la población civil, se reitera dos veces en el siguiente fragmento, que incorpora los testimonios del cooperativista y de un "viejito" que vive en una de las llamadas aldeas modelo organizadas por el ejército para controlar a la población civil. Éste declara que "los guerrilleros huyeron al monte y no nos protegieron como habían jurado...” (79), mientras el cooperativista repite la crítica de la guerrillera al señalar que a la guerrilla sólo le interesa mantener intacta su estructura militar: “[...] la guerrilla nos usa como carne de cañón, como el ejército usa a los patrulleros y los soldados [...] cuando viene el ejército ellos se enmontañan y se preocupan de su estructura militar y después dicen que las cosas andan bien, que sólo la población civil ha sido masacrada [...]” (59). Y por último, Morales incluye el testimonio de uno de los colaboradores del ejército, un comisionado militar indígena que coordina las patrullas de autodefensa

\footnotetext{
9 Morales dedica un capítulo a este incidente en su testimonio personal, Los que se fueron por la libre, publicado por entregas en un diario guatemalteco a fines de 1996 y principios de 1997. Los guerrilleros masacrados pertenecían al grupo insurgente de Morales, el Movimiento Revolucionario del Pueblo IXIM, una organización independiente de la Unidad Revolucionaria Nacional Guatemalteca (URNG), la coalición de las principales agrupaciones guerrilleras, entre las cuales se encontraba el EGP. La masacre tuvo lugar en 1983 mientras el autor hacía trabajo internacional en Nicaragua, y le tocó denunciar antes los aliados internacionales (los sandinistas, los cubanos y los soviéticos) esta masacre perpetrada por el EGP contra otra organización revolucionaria (90-93).

ISSN 0034-9631 (Impreso)
} 
civil. ${ }^{10}$ Éste defiende la actuación del ejército en los pueblos y hace eco de las críticas de la guerrilla articuladas por las otras voces:

El ejército no nos ha mentido, en cambio el guerrillero sínos mintió. Porque el guerrillero dijo, los vamos a liberar dijo, vamos a tomar el poder para ustedes los indios. Y no cumplió. En cambio el ejército dijo, ustedes colaboran con los guerrilleros y por eso los vamos a matar, indios cabrones. Y el ejército cumplió. Ellos los del ejército hablan claro, no como los guerrilleros que andan diciendo linduras pero también matan por gusto a la gente que no quiere darles comida ni irse con ellos al monte [...] (113)

Otra expresión repetida, “torear al ejército” (43, 46, 49, 151, 162, 165), señala la relación entre éste y los que persigue: los guerrilleros y las Comunidades de Población en Resistencia. Por un lado, se evoca la imagen de un ejército de mucha fuerza pero poca inteligencia que arremete ciegamente contra su adversario. Pero por otro lado, se sugiere la debilidad de la guerrilla, que se ve obligada a huir ante los ataques del ejército. La guerrilla testimoniante confiesa que para 1981 y 82, “[...] La verdad era que por ese tiempo las columnas guerrilleras ya no podían bajar de la montaña porque el ejército andaba por todos lados [...] no nos acercábamos al pueblo pero bajábamos a cada rato a los caseríos toreando al ejército, y cuando alguna patrulla era débil la emboscábamos. Tal vez por eso fue que el ejército comenzó con lo de las patrullas de autodefensa civil [...]” (46). El miembro de las CPR utiliza la expresión cinco veces en su testimonio al relatar este juego mortífero de gato y ratón entre el ejército y las CPR, en el que, también sirviéndose de la repetición anafórica de “todo lo queman” y “todo lo matan” (150), el sobreviviente de la violencia enumera prolijamente los detalles de la campaña de tierra arrasada del ejército. Para estos indígenas indefensos que se niegan a abandonar su tierra natal, esta estrategia de esconderse en las montañas y en las selvas es su única opción: “[...] por eso nosotros también decidimos venirnos para la montaña con nuestros paisanos a ver si aquí, caminando siempre, dando vueltas, toreando al ejército, podemos salvarnos de la muerte [...]” (151).

Las referencias repetidas al Corazón del Cielo y la espiritualidad maya (59, 68, 123 , 142, 143-44, 147, 152-53, 156, 164) subrayan la importancia de la religión para el pueblo

10 Las patrullas de autodefensa civil, junto con las masacres y la creación de las aldeas modelo o polos de desarrollo, eran las tácticas empleadas para realizar la estrategia militar de "quitarle el agua al pez" (114) en su lucha contra la guerrilla. Se obligaba a todos los hombres del pueblo a prestar servicio en estas patrullas, y sus órdenes eran terminantes: buscar subversivos y matar o entregarlos al ejército. La negativa a cumplir ciegamente estas órdenes se castigaba con la muerte. Al final del fragmento que narra la masacre en Rabinal, el narrador describe la organización de las patrullas y la tortura y ejecución de un hombre ya viejo y su hijo, porque aquél había indicado que estaba dispuesto a formar parte de la patrulla, pero que no mataría por sus creencias religiosas. Los soldados se los llevaron, los machetearon y los colgaron de un árbol, y antes de morir, el kaibil Toribio oyó al viejo decir: "Gracias a Dios mi hijo tampoco se manchó las manos con la sangre de un hermano” (84).

Revista Iberoamericana, Vol. LXXVI, Núms. 232-233 Julio-Diciembre 2010, 583-600 ISSN 0034-9631 (Impreso) 
maya, y la información transmitida a través de estos pasajes explica cómo los mayas dan sentido a sus circunstancias tan trágicas y encuentran esperanza entre las cenizas de su holocausto. Aunque se introduce la espiritualidad en los testimonios del cooperativista y la catequista en la primera sección del libro, se desarrolla el tema principalmente en la última sección por medio del testimonio del brujo y especialmente el del miembro de las CPR. El brujo narra la causa del castigo de los mayas, el "pecado original" de hacerse amigos de los dioses de Xibalbá (144) que ha ocasionado el centenario sufrimiento de su pueblo bajo el dominio de Xibalbá en sus múltiples formas. El miembro de las CPR profetiza que "sólo faltan unos pocos años para la liberación total" (153), ya que "esta noche negra está por terminarse: que Kukulkán va a volar más alto que el cóndor y el águila real [...] y que los indios volveremos a ser felices pegados a nuestras tierras [...]” (156). Kukulkán, figura análoga al Jesús salvador del cristianismo, brinda la misma promesa de redención a los fieles que preservan la Costumbre y mantienen la fe en Él (144).

En fin, se emplea el recurso de la repetición para destacar los ya mencionados y otros aspectos importantes de esta realidad testimoniada -la explotación económica de los indígenas, el papel de la iglesia católica en la organización de los pueblos indígenas para acabar con la miseria y la injusticia, la represión brutal llevada a cabo por el ejército-y para enlazar los diversos hilos narrativos del libro. Un último ejemplo digno de mención de la técnica, ya que sirve de justificación para este modelo testimonial polifónico, se encuentra en el penúltimo fragmento, el del miembro de las CPR. Éste utiliza la frase "la gente reacciona distinto" cuatro veces $(156,158,161,163)$ al presentar diversas reacciones de la gente ante la represión y el sufrimiento experimentados en las montañas: la resistencia heroica de doña Concepción Bay, una viejita de casi 80 años, pese al asesinato de sus cuatro hijos (157-58); la decisión de Tenchita, maestra de escuela que sobrevivió la masacre de Rabinal, tras largas privaciones en la montaña, de llevar a los niños que rescató a la costa en busca de refugio (158-61); los que se rindieron y se entregaron al ejército para ser interrogados, posiblemente torturados y matados, y si les toca suerte, asentados en las aldeas modelo descritas como "campos de concentración” $(161,163)$; y los miles que optaron por cruzar la frontera a México y vivir en campamentos de refugiados, muchos de ellos también en situaciones muy precarias (161-63). Al enumerar estas diferentes reacciones a las condiciones de extrema pobreza y violencia, la voz testimoniante parece afirmar implícitamente la necesidad de múltiples voces y perspectivas para captar y transmitir la diversidad de reacciones de la población indígena ante la dura realidad que enfrenta.

Lo comentado hasta aquí ya ofrece una muestra de la riqueza de perspectivas representadas en Señores bajo los árboles. Aunque se incorpora algo la perspectiva del ejército a través de los trozos del manual militar, el fragmento del comisionado militar -quien proclama que "el kaibil es el salvador del país y de los valores de todos: Dios, Patria, Libertad, Trabajo y Familia” (116)-y los fragmentos que narran los hechos desde

\footnotetext{
Revista Iberoamericana, Vol. LXXVI, Núms. 232-233 Julio-Diciembre 2010, 583-600
ISSN 2154-4794 (Electrónico)
} 
el punto de focalización de Toribio de León, el ex cohetero y kaibil, es obvio que al autor le importa privilegiar los testimonios de las víctimas de la violencia. ${ }^{11}$ Se incorpora más de una docena de voces testimoniantes individualizadas que cuentan sus experiencias. La activista y guerrillera maya del primer fragmento narrado en primera persona, por ejemplo, relata su participación en las organizaciones Acción Católica (AC) y en el Comité de Unidad Campesina (CUC), y cómo su contacto con don Vicente Menchú, padre de Rigoberta y dirigente del CUC, contribuyó a su concientización y la de muchos más en su aldea ubicada en el departamento de El Quiché (38-39). Explica cómo en 1980 llegó la represión militar a su aldea, dirigida contra "catequistas, cooperativistas y gente del CUC” (40), y afirma que para "fines del 82, más del diez por ciento de la población india había sido masacrado y los sobrevivientes que huían del ejército eran más de un millón [...]” (42). La activista, tras sobrevivir varias masacres y pasar tiempo huyendo y escondiéndose del ejército en la montaña, decidió unirse a una columna del Ejército Guerrillero de los Pobres (EGP), "porque uno de indio sentía que al fin había llegado la hora de que alguien nos hablara desde nuestro dolor y uno sentía que era posible que nos respetaran y que nos temieran [...]" (43).

Las demás voces añaden otros pedazos del mosaico y reiteran los tétricos aspectos comunes de la violencia. En varias ocasiones, el autor intercala múltiples testimonios en un solo fragmento a fin de examinar distintos aspectos de la represión y las reacciones de las víctimas. En el fragmento que sigue al de la activista, se combina el testimonio de un cooperativista que se refugió en México con el de un viejito de la misma aldea que se entregó al ejército y fue asentado en una aldea modelo (51-59). En el fragmento que denuncia la usurpación de tierra indígena localizada cerca de Antigua por un licenciado (119-36), se entretejen los testimonios de un testigo indígena inicial, de su comadre desesperada (recopilada en letra cursiva) que se subleva y actúa, del indígena que dirigió el asalto a la finca del licenciado tras las amenazas de muerte y otros abusos (también en letra cursiva) y el narrador autorial que evoca el contradictorio legado histórico de la capital colonial de Antigua (representada en letra cursiva y negritas). Ya se ha examinado el fragmento del miembro de las CPR, que incorpora los testimonios indirectos y las reacciones distintas de otros miembros de las comunidades (148-65).

Además de estas voces, otras que brindan diversas perspectivas valiosas son: una catequista que denuncia la explotación económica en su región natal y en las fincas de la costa, y las masacres cometidas por el gobierno del general Ríos Montt en las aldeas de Rabinal (68); el responsable local del Frente Guerrillero de la Estrella (en formación) que le informó al dirigente del Movimiento Revolucionario del Pueblo IXIM de la masacre alevosa de sus 32 compañeros por los que deberían ser sus compañeros en armas, los

${ }^{11}$ Convendría enfatizar que Toribio, el verdugo de innumerables hermanos indígenas, se presenta no sólo como victimario sino también como víctima, uno de los miles de indios jóvenes reclutados a la fuerza y obligados a masacrar a su propia gente o ser matados por el ejército (43).

$\begin{array}{llrrr}\text { Revista Iberoamericana, Vol. LXXVI, Núms. 232-233 Julio-Diciembre 2010, 583-600 } & \text { ISSN 2154-4794 (Electrónico) }\end{array}$ 
guerrilleros del EGP (117-18); el director de una película que pretende documentar los sucesos ocurridos en las aldeas alrededor del lago de Atitlán entre 1979 y 1985 (94-112); y el brujo maya cuyos seis fragmentos proporcionan el marco cultural a las tres secciones formales de fragmentos. También se incluye un testimonio anónimo ${ }^{12}$ en primera persona, que se coloca inmediatamente antes del fragmento narrado en tercera persona que cuenta la masacre de Rabinal. El testimonio anónimo no nombra el pueblo donde se comete la matanza sangrienta, pero la narración comienza con la fecha exacta, el 15 de septiembre del 81, Día de la Independencia, dato que permite precisar que se trata también de la masacre de Rabinal (Oj K’aslik Estamos Vivos 195). A diferencia de las voces y los lugares más claramente perfilados, este carácter anónimo tanto de la voz testimoniante como del lugar de la masacre podría representar a los miles de víctimas anónimas y los centenares de masacres perpetrados en pequeñas aldeas mayas desconocidas para el resto del mundo.

Morales declara en el prólogo a la segunda edición que la estética testimonial del horror en que se fundamenta su modelo testimonial se infiere del compromiso ético del escritor, y por consiguiente, "la testinovela debería evitar: 1) la denuncia que apela a la compasión que denigra; 2) el efectismo que le resta fuerza a la verdad cándida y horrible del testimonio; y 3) el desbordamiento de técnicas narrativas por encima del elemento estructurador del texto: la testimonialidad" (11). A mi parecer, el autor se mantiene fiel a estos preceptos en Señores bajo los árboles. Sin duda alguna, la narración de la violencia terrorífica dirigida contra la población civil indígena suscita el horror y la compasión del lector, pero lo que más llama la atención es la dignidad y el estoicismo de las voces testimoniantes. Los sobrevivientes relatan los trágicos eventos que han presenciado y sufrido desapasionadamente, lo cual hace resaltar su dignidad humana. De hecho, es algo chocante el tono tan objetivo y carente de emoción ${ }^{13}$ con el que se narran escalofriantes sucesos injustos y violentos, una actitud narrativa reminiscente del realismo mágico, cuyos narradores también cuentan acontecimientos fantásticos e

12 Todos los narradores testimoniales son anónimos en el sentido de no identificarse por nombre, pero sí cuentan sus antecedentes familiares y sus experiencias personales. Del narrador de este fragmento, no sabemos ni si es hombre o mujer. Se limita a dar testimonio de tres masacres que presenció y de unos muertos más que resaltan la barbarie del ejército -los kaibiles que sacaban y se comían los corazones de sus víctimas (72)- y su estrategia de destruir totalmente la comunidad, ilustrada por la tortura y el asesinato desalmados de la Nana Andrea Osorio, cuyo "único pecado fue enseñar a las mujeres las propiedades nutritivas de los alimentos" (73),

${ }^{13}$ En el prólogo, Morales describe la fuerte reacción emocional que sintió al leer los testimonios y al conocer en una cuantas entrevistas que él mismo realizó con sobrevivientes indígenas, "el lenguaje corporal, las estrategias discursivas, el tono emocional y la simplicidad desarmante con las que los testigos del horror contrainsurgente manifestaban sus experiencias en vivo” (8). Se pierde gran parte del lenguaje no verbal del testimonio oral en la transcripción escrita, pero aun así, es notable la capacidad de este discurso testimonial escrito tan lacónico, directo y aparentemente objetivo de conmover a un lector medianamente sensible.

$\begin{array}{llrr}\text { ISSN 0034-9631 (Impreso) } & \text { ISSN 2154-4794 (Electrónico) }\end{array}$ 
inverosímiles con aplomo asombroso.

Como parte de su propuesta estética, el autor también incorpora elementos mitológicos y magicorrealistas en la obra. Según Morales, algunos críticos han alegado que "la juntura de mitologías y realismo mágico con horror contrainsurgente es poco menos que cínica” (14), pero se defiende de esta acusación recordando las observaciones y la recomendación del insigne intelectual y escritor guatemalteco Luis Cardoza y Aragón, quien afirma referente a las novelas indigenistas: "La realidad de los genocidios aleja lo pintoresco y a lo que tiende a distraernos de lo concreto. ¿Por qué no lo concreto y también lo mítico?” (14) La espiritualidad y las creencias religiosas forman una parte esencial del mundo maya e influyen poderosamente en la vida cotidiana, lo cual justifica su inclusión en esta estética testimonial. Ya se ha comentado arriba la presencia de la espiritualidad maya en numerosos fragmentos del libro y su función explicativa de vincular el pasado con el presente, de dar sentido a la represión actual que sufren y de ofrecer esperanza para el porvenir.

El realismo mágico desempeña un papel más reducido en el libro, pero se nota su presencia en dos ocasiones. La primera corresponde al cuarto y al quinto fragmentos del brujo, en los que éste afirma el poder de los brujos de desaparecer (144) y de "volar o transformarse en animales o en mujeres o en jóvenes cuando en realidad son hombres y ya están medio viejos" (143). Y al sostener que la represión actual ha sido una prueba más dura que la guerra de conquista, el brujo ratifica este juicio declarando: "Se lo digo yo, que he estado en las dos” (147). Además de los poderes sobrenaturales de los brujos, el realismo mágico surge en las últimas páginas de la denuncia de la usurpación de tierras indígenas (131-36), ya que en esta parte el narrador es un muerto. El jefe del asalto a la finca del licenciado, quien narra esta última parte del fragmento, es detenido por la tropa, torturado perversamente hasta fallecer, y tras la muerte, su espíritu prosigue la narración testimonial. Como espíritu, es capaz de anticipar y presenciar otros asesinatos relacionados con la toma de las tierras, y se juntan con él varios otros espíritus de los justos que perdieron sus vidas. El muerto termina su testimonio afirmando: “[...] Nosotros los muertos deambulamos por ahí también, velando, penando, esperando que esta incómoda calma termine de una vez por todas para poder ir a descansar en paz junto al calor de Corazón del Cielo, que nos llama y nos llama y nos llama para volver a nacer y volver a luchar [...]" (136). Este pasaje del libro ilustra de nuevo cómo se puede utilizar los recursos de la ficción para extender la denuncia testimonial de la injusticia social.

Se han examinado varios recursos utilizados por el autor para enlazar y unir los fragmentos testimoniales de la obra, pero también convendría comentar brevemente lo que hace para brindar variedad y mantener el interés, puesto que la repetición incesante de abusos y violaciones de los derechos humanos podría a la larga anonadar y cansar al lector. Por un lado, ya se ha estudiado la variedad de perspectivas y tipos de narración representada en la obra. Otro recurso prevalente en la segunda y la tercera

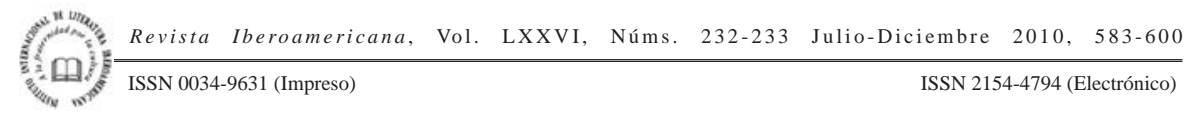


sección de la testinovela es el empleo de diferentes formas discursivas. El fragmento extenso (94-112) que resume los acontecimientos y los abusos cometidos en las aldeas circundantes al lago de Atitlán se narra mediante lo que parece ser el guión del director de una película documental, que incluye acotaciones referentes a los antecedentes, los eventos presentados, las tomas de cámara, las didascalias que se usarán, etcétera, junto con los comentarios del director, todo separado por rayas (/ /) a lo largo del fragmento. La denuncia de la masacre de hermanos rebeldes realizada por los guerrilleros del EGP se hace a través de la epístola del responsable local sobreviviente (117-18). La perspectiva militar se expresa en otro fragmento (137-42) por medio de los trozos recopilados del instructivo militar y la información apuntada en el diario del kaibil Toribio de León. Y por último, la inclusión de los dos pasajes de estilo más figurado y ampuloso para evocar la ciudad de Antigua (127-29) y a los brujos de la antigüedad (143-44) también rompe la uniformidad del lenguaje literario más directo usado para las otras voces testimoniantes y agrega variedad e interés al relato testimonial.

Si bien predomina en el libro la denuncia de los horrorosos abusos perpetrados contra la población civil indígena a través de esta selección polifónica de voces testimoniantes, es preciso señalar que la obra también pone de manifiesto el fracaso de la política de terror y genocidio emprendida contra la cultura maya. El título de la testinovela la vincula con la conquista española liderada por Pedro de Alvarado, el capitán de Cortés que llegó en 1524 con sus aliados tlaxcaltecas, tras la conquista del imperio azteca, a “La Tierra de los Árboles” para someter a “Los Señores Bajo los Árboles” (82). A pesar de la derrota de los quichés por los españoles debido a las rivalidades entre las etnias mayas y su incapacidad de unirse para luchar contra el enemigo común invasor, y pese a casi quinientos años de explotación y represión y la actual campaña de exterminio, el miembro de las CPR del penúltimo fragmento declara con orgullo para concluir su testimonio que "nosotros seguimos de pie como nuestros antepasados, llevando agua y sol pero de pie, de pie siempre ya sea en la montaña o en la selva: de pie bajo los árboles [...]” (165). ${ }^{14}$

Como propuesta testimonial alternativa, Señores bajo los árboles logra a mi juicio los objetivos éticos y estéticos delineados por Mario Roberto Morales en sus entrevistas y en el prólogo a la segunda edición del libro. El autor concluye el prólogo afirmando:

\footnotetext{
${ }^{14}$ Esta proclamación anticipa el título del reciente testimonio documental Oj K’asklik Estamos Vivos, que intenta recuperar la memoria histórica de los años de violencia que resultaron en la matanza por grupos militares y paramilitares del 20\% de la población del municipio de Rabinal, más de 4.400 personas, en sólo el período comprendido entre 1981 y 1983 (276). La obra documenta la represión y analiza las estrategias y los mecanismos de la violencia, pero también celebra la supervivencia del pueblo maya: "A pesar de todas las brutalidades desde hace siglos hasta la violencia durante el conflicto armado interno, a pesar de que nos quisieron terminar a todos: ¡Estamos vivos! A pesar de todo el sufrimiento y el / daño, no nos han podido aniquilar como pueblo maya-achí y seguimos vivos con nuestra propia identidad cultural" (18-19).

Revista Iberoamericana, Vol. LXXVI, Núms. 232-233 Julio-Diciembre 2010, 583-600
ISSN 2154-4794 (Electrónico)
} 
“[...] mi libro permanece, creo, como un documento que habrá de seguir cumpliendo funciones de registro histórico, de transmisión de la memoria, de alegato acusatorio y de propuesta estética e identitaria de nuestros mestizajes culturales y políticos” (18). Es fácil comprobar que en la Guatemala de los años noventa, el testimonio ha influido, como sugiere Sophia A. McClennen, en la redefinición de la literatura de la misma manera que el documental social latinoamericano ha transformado la función social del cine (72). Por sólo mencionar unos cuantos ejemplos de la misma época de Señores bajo los árboles, se podría citar La otra cara (1992) y El retorno de los mayas (1998) de Gaspar Pedro González, En el filo (1993) y Los muchachos de antes (1996) de Marco Antonio Flores, las tres novelas testimoniales de José Flores $(1994$ ?, 1997, 1997) y El rebelde olvidado (1997) de Marco Antonio Ordóñez Madrid, para demostrar el compromiso asumido por los escritores guatemaltecos de contar la verdad sobre el violento conflicto armado que sacudía su país desde hacía más de tres décadas.

Más de una década después de la firma de los llamados acuerdos de paz firme y duradera, el modelo testimonial de Morales, concretado en su obra Señores bajo los árboles, sigue señalando un camino para los literatos dispuestos a poner su arte al servicio de la recuperación de la memoria histórica. Esta propuesta estética testimonial añade un eslabón más a la larga tradición de la literatura de emergencia latinoamericana, pero desgraciadamente, el fin formal del conflicto armado interno parece haber quitado el sentido de urgencia, a pesar de la persistencia de las injusticias económicas, políticas, sociales y culturales que dieron origen a la guerra civil, y pese al alto nivel de violencia e inseguridad que sigue caracterizando la vida diaria de las etnias mayas y del pueblo guatemalteco en general. No obstante, el gran logro de Mario Roberto Morales, la creación literaria de un mosaico de voces testimoniantes que brinda una representación matizada de esta trágica realidad histórica, constituye un modelo viable para dar voz a los oprimidos - una voz no menos real por el aporte de la ficción- y para difundir perspectivas silenciadas por la historia oficial y denunciar los abusos perpetrados por los poderosos contra los pobres y explotados.

\section{BiBLIOGRAFÍA}

Arias, Arturo. The Rigoberta Menchú Controversy. Minneapolis and London: The U of Minnesota P, 2001.

Beverley, John. Testimonio: On the Politics of Truth. Minneapolis and London: The U of Minnesota P, 2004.

Flores, José. Ciudades bajo los árboles. Guatemala: Editorial Estudiantil Fenix, 1997. El verde púrpura. Guatemala: s.n., 1990-94?

Sombras de selva. Guatemala: Editorial Estudiantil Fenix, 1997.

Flores, Marco Antonio. En el filo. México: Editorial Praxis, 1993.

Revista Iberoamericana, Vol. LXXVI, Núms. 232-233 Julio-Diciembre 2010, 583-600
ISSN 2154-4794 (Electrónico) 
Los muchachos de antes. México: Alfaguara, 1996.

González, Gaspar Pedro. El retorno de los mayas. Guatemala: Fundación Myrna Mack, 1998.

La otra cara. Guatemala: Editorial Cultura, 1992.

Guízar Álvarez, Eduardo. "Entrevista con Mario Roberto Morales”. Torre de Papel 9/3 (octubre 1999): 94-98.

Hood, Edward Waters. "Entrevista con Mario Roberto Morales: La novela y el testimonio en Centroamérica”. Alba de América: Revista Literaria 14/26-27 (julio 1996): 529-45.

Janssens, Bert y otros. Oj K’aslik Estamos Vivos: Recuperación de la memoria historia de Rabinal (1944-1996). Rabinal, Baja Verapaz: Museo Comunitario Rabinal Achí, 2003.

McClennen, Sophia A. “Are Cultural Studies 'Against Literature'? Reading Testimonial and Film in the Latin American Canon". Woman as Witness: Essays on Testimonial Literature by Latin American Women. Linda S. Maier y Isabel Dulfano, eds. New York: Peter Lang, 2004. 63-80.

Menchú, Rigoberta y Elisabeth Burgos Debray. Me llamo Rigoberta Menchú y así me nació la conciencia. 15 ed. México: Siglo Veintiuno Editores, 1998.

Morales, Mario Roberto. Los que se fueron por la libre. 2a ed. Guatemala: Editorial Consucultura, 2008.

Señores bajo los árboles. 2a ed., 1a ed. 1994. Guatemala: Editorial Cultura, 2007.

Stoll-Menchú: la invención de la memoria. Mario Roberto Morales, ed. Guatemala: Editorial Consucultura, 2001.

Ordóñez Madrid, Marco Antonio. El rebelde olvidado. Guatemala: Editorial Oscar de León Palacios, 1997.

Rohter, Larry. "Tarnished Laureate: Novel Winner Accused of Stretching the Truth in her Autobiography”. New York Times (Dec. 15, 1998).

Stoll, David. Rigoberta Menchú and the Story of all Poor Guatemalans. Boulder: Westview Press, 1999.

White, Hayden. The Content of the Form: Narrative Discourse and Historical Representation. Baltimore: The Johns Hopkins UP, 1987.

Revista Iberoamericana, Vol. LXXVI, Núms. 232-233 Julio-Diciembre 2010, $583-600$
ISSN 0034-9631 (Impreso) 